\title{
Immunomodulatory Effects of Amphotericin-B on Cellular Cytotoxicity of Normal Human Lymphocytes ${ }^{1}$
}

\author{
Madhavan P. N. NaIR ${ }^{2}$ and Stanley A. Schwartz \\ Departments of Pediatrics and Epidemiology, The University of Michigan, \\ Ann Arbor, Michigan, 48109
}

Received February 22, 1982; accepted April 21, 1982

\begin{abstract}
Human peripheral blood lymphocytes (PBL) precultured in media demonstrated decreascd NK and ADCC activities as an apparent consequence of endogenous suppressor cells generated in the culture. PBL precultured with amphotericin-B (AMB) for $48 \mathrm{hr}$ showed further decreases of NK and ADCC activities. T cells, Sephadex G-10 column passed PBL, and NKand ADCC-enriched subpopulations separated on a Percoll gradient precultured with AMB also manifested decreased NK and ADCC activities. In mixing experiments, lymphocytes precultured with AMB suppressed the ADCC activities of fresh autologous effector cells. The suppression of ADCC activities observed was not due to crowding, selective toxicity, steric hindrance, effector or target cell death from AMB or desoxycholate, or the presence of PBL causing cold target competitive inhibition or binding. AMB-enhanced suppression was not reversed by indomethacin. The results suggest that AMB has a significant immunomodulating effect on human PBL possibly by activating endogenous suppressor cells which may be of clinical significance.
\end{abstract}

\section{INTRODUCTION}

Amphotericin-B (AMB), ${ }^{3}$ a polyene antibiotic, is clinically important in the treatment of systemic fungal infections. Using in vitro and in vivo models, several investigators have demonstrated both immunostimulatory (1-5) and immunosuppressive effects (6-9) of AMB in human and animal systems. The immunostimulatory effect of AMB may be a useful adjunct to host defenses against fungi, while the immunosuppressive activity may have deleterious effects.

Natural killer (NK) cells and cells mediating antibody-dependent cellular cytotoxicity (ADCC) have been gaining attention because of a possible role in defense against tumors and in the regulation of lymphoid cell functions (10-15). The present

\footnotetext{
'Aided by grants from the U.S. Public Health Service, AI-16216; and the Children's Leukemia Foundation of Michigan.

${ }^{2}$ Requests for reprints should be addressed to Madhavan P. N. Nair, The University of Michigan, Department of Epidemiology, School of Public Health I, Room 2022, Ann Arbor, Michigan, 48109.

${ }^{3}$ Abbreviations used: ADCC, antibody-dependent cellular cytotoxicity; AMB, amphotericin-B; CEM, human T-lymphoblastoid cell line; E:T, effector:target; FCS, fetal calf serum; HBSS, $\mathrm{Ca}^{2+}$ - and $\mathrm{Mg}^{2+}$ free Hanks' balanced salt solution; INDO, indomethacin; K-562, human erythroleukemia cell line; MEM, minimal essential medium; MNC, mononuclear cells; NK, natural killer; PBL, peripheral blood lymphocytes; SB, human B leukemia cell line; SD, sodium desoxycholate; S:E, suppressor:effector.
} 
experiments were designed to investigate the effects of AMB on NK and ADCC activities of normal human peripheral blood lymphocytes (PBL). We have recently shown that precultured PBL can develop suppressor cell activities as a possible consequence of an autologous mixed lymphocyte culture reaction (16). In the present study, normal PBL were precultured with and without AMB and tested for their potential cytotoxicity against prelabeled target cells. We observed that normal PBL precultured with AMB manifest greater decreases in NK and ADCC activities compared to control PBL precultured without AMB. In mixing experiments, lymphocytes precultured with AMB suppressed the ADCC activities of fresh autologous effector cells. These data suggest that AMB has a significant immunomodulating effect on human PBL possibly by activating suppressor cells which may be of clinical significance.

\section{MATERIALS AND METHODS}

Drugs. AMB (E. R. Squibb \& Sons, Princeton, N.J.) was supplied in sterile lyophilized form containing sodium desoxycholate (SD) as a solubilizer and sodium phosphate as a buffer. SD was obtained from Sigma Chemical Co., St. Louis, Mo. AMB and SD were initially dissolved in small aliquots of distilled water and then further diluted with RPMI 1640 medium. Indomethacin (INDO) (Sigma Chemical Co.) was dissolved initially in 95\% ethyl alcohol and diluted further in RPMI 1640 medium.

Lymphocyte donors. Peripheral blood from healthy donors of both sexes, aged 25 to 40 years, was drawn into a plastic syringe containing heparin $(20 \mathrm{U} / \mathrm{ml})$. Donors were apprised of the study and consents were obtained consistent with the policies of The University of Michigan and the National Institutes of Health.

Isolation of lymphocytes. PBL were isolated from heparinized venous blood using a modified method of Böyum (17). Blood was diluted with an equal volume of calcium and magnesium-free Hanks' balanced salt solution (HBSS) (GIBCO, Grand Island, N.Y.) and centrifuged at $400 \mathrm{~g}$ for $30 \mathrm{~min}$ at $18^{\circ} \mathrm{C}$. The mononuclear cell band was harvested, washed three times with HBSS, and resuspended in RPMI 1640 medium, containing $25 \mathrm{mM}$ HEPES buffer supplemented with $5 \%$ heat inactivated fetal calf serum (FCS) (GIBCO), $80 \mu \mathrm{g} / \mathrm{ml}$ gentamicin (Schering Corp., Kenilworth, N.J.), and $300 \mu \mathrm{g}$ fresh glutamine/ml (complete medium).

Depletion of adherent cells. Mononuclear cells were depleted of adherent cells by the method of Ly and Mishell (18) as modified by Berlinger et al. (19). PBL were suspended in RPMI 1640 with $10 \%$ FCS, and passaged through a 7 -ml column of Sephadex G-10 beads (Pharmacia Fine Chemicals, Piscataway, N.J.), equilibrated in the same medium. After $45 \mathrm{~min}$ of incubation at $37^{\circ} \mathrm{C}$, nonadherent cells were washed through with one bed volume of warm $\left(37^{\circ} \mathrm{C}\right)$ medium. The cell recovery was $>70 \%$ of the total input, and macrophage contamination as indicated by nonspecific esterase staining was $<2 \%$.

Preparation of $T$ cells. T cells were prepared as described elsewhere (20). Briefly, $4 \times 10^{6} \mathrm{PBL}$ depleted of adherent cells were mixed with $0.25 \mathrm{ml}$ of heat-inactivated FCS preabsorbed with sheep red blood cells (SRBC) and $1 \mathrm{ml}$ of $1 \%$ packed volume neuraminidase treated $(25 \mathrm{U} / \mathrm{ml}$ in a $5 \%$ SRBC suspension) SRBC. The mixture was incubated at $37^{\circ} \mathrm{C}$ for $5 \mathrm{~min}$ and centrifuged at $200 \mathrm{~g}$ for $5 \mathrm{~min}$ followed by incubation at $4^{\circ} \mathrm{C}$ for $1 \mathrm{hr}$. The pellets were gently resuspended and $\mathrm{T}$ lymphocytes rosetted with SRBC were separated from non-T lymphocytes on a Ficoll-Hypaque 
(Pharmacia) density gradient by centrifugation at $480 \mathrm{~g}$ for $20 \mathrm{~min}$ at $20^{\circ} \mathrm{C}$. SRBC attached to the isolated $\mathrm{T}$ lymphocytes (pellet) were lysed by hypotonic treatment with $1 \mathrm{ml}$ of distilled water, followed by $1 \mathrm{ml}$ of double-strength minimal essential medium (MEM, GIBCO). T cells were washed three times with RPMI 1640 and resuspended in complete medium and preincubated for $24 \mathrm{hr}$ before use.

Percoll fractionation of lymphocytes. The enrichment of NK and ADCC effector cells using a discontinuous gradient of Percoll (Pharmacia) was carried out as described elsewhere (21). To prepare a discontinuous density gradient, Percoll solution was mixed at various concentrations with RPMI 1640 medium, and 2-ml aliquots (ranging from 50.0 to $37.5 \%$ in $2.5 \%$ increments) were gently layered into $15 \times 130-\mathrm{mm}$ round bottom glass test tubes. Adherent cell-depleted lymphocytes were layered on top of the gradient and centrifuged at $300 \mathrm{~g}$ for $45 \mathrm{~min}$ at $20^{\circ} \mathrm{C}$. Six fractions, with the uppermost $(37.5 \%)$ designated " 0 " and the lowermost (50.0\%) designated "V", were collected from the top with a Pasteur pipet and washed twice in RPMI 1640 medium. Recovery of cells was $85 \%$ of the input, and viability always exceeded $95 \%$ by trypan blue dye exclusion.

In vitro incubation of cells with $A M B$. Total PBL, PBL depleted of adherent cells, $T$ cells, non-T cells, and various Percoll separated fractions were suspended in complete medium at a concentration of $1 \times 10^{6}$ cells $/ \mathrm{ml}$ to which either AMB or SD was added at concentrations of $0.1,0.5,1,2.5,5$, and $10 \mu \mathrm{g} / \mathrm{ml}$ of culture. A duplicate set of cultures received RPMI 1640 medium without drugs as controls. Cell cultures were incubated for up to $72 \mathrm{hr}$ in a humidified environment of $5 \%$ $\mathrm{CO}_{2}$ in air at $37^{\circ} \mathrm{C}$. Cells were washed three times and resuspended in complete medium. Cell viability was comparable with that of control cultures as determined by trypan blue exclusion, was not affected by concentrations of $\leq 5 \mu \mathrm{g} \mathrm{AMB} / \mathrm{ml}$, and was $>85 \%$. Treated cultures and controls were tested for their ability to mediate NK and ADCC activities, and were examined for immunoregulatory activities in coculture experiments.

Tumor target cells. The human erythroleukemia cell line, K-562, and T lymphoblastoid cell line, CEM, were used as targets for NK cells. For the ADCC assay, we chose as targets a human B-cell leukemia line (SB) because of resistance to $\mathrm{NK}$ activity in a $4 \mathrm{hr}{ }^{51} \mathrm{Cr}$ release assay.

Preparation of target cells. Passaged 48-hr-old target cells were washed twice with complete medium. To $0.8-\mathrm{ml}$ aliquots of complete medium containing $5 \times 10^{6}$ tumor cells, $200 \mu \mathrm{Ci}$ of ${ }^{51} \mathrm{Cr}$ as sodium chromate (New England Nuclear, Boston, Mass.) was added. The cells were incubated at $37^{\circ} \mathrm{C}$ for $1 \mathrm{hr}$ in a humidified atmosphere of $5 \% \mathrm{CO}_{2}$ in air with intermittent shaking. Following incubation, the cells were washed three times with complete medium and resuspended to a concentration of $2 \times 10^{5}$ cells $/ \mathrm{ml}$.

Assay for NK activity. NK activity was determined in a direct ${ }^{51} \mathrm{Cr}$ release assay as previously described $(16,22,23)$. Briefly, varying concentrations of viable effector cells in complete medium were added to triplicate cultures of ${ }^{51} \mathrm{Cr}$-labeled target cells in $0.2 \mathrm{ml}$ volumes in V-bottom microtitration plates (Dynatech Labs, Alexandria, Va.). After centrifugation at $40 \mathrm{~g}$ for $2 \mathrm{~min}$, they were incubated at $37^{\circ} \mathrm{C}$ in a humidified atmosphere of $5 \% \mathrm{CO}_{2}$ in air for $4 \mathrm{hr}$. Percentage cytotoxicity was calculated as follows:

$$
\% \text { cytotoxicity }=\frac{\text { experimental release }- \text { spontaneous release }}{\text { total release }- \text { spontaneous release }} \times 100
$$


where spontaneous release represents counts released from control wells containing only $2 \times 10^{4}$ target cells, and total release represents counts obtained in an aliquot of $2 \times 10^{4}$ lysed target cells.

Assay for ADCC. The ADCC activity of effector cells was determined by the original method of Perlmann and Perlmann (24) as modified by Handwerger and Koren (25). Briefly, $50 \mu \mathrm{l}$ of varying concentrations of effector cells was added to $50 \mu \mathrm{l}$ of complete medium containing ${ }^{51} \mathrm{Cr}$-labeled SB target cells and $100 \mu \mathrm{l}$ of a $2 \times 10^{-4}$ dilution of rabbit anti-SB antisera previously found to yield maximal ADCC. Percentage ADCC activity was calculated as described above for NK activity with the following exceptions. Spontaneous release represents counts released in control wells containing effector cells, labeled SB target cells, and media instead of anti-SB antibodies, and total release represents counts obtained in an aliquot of $1 \times 10^{4}{ }^{51} \mathrm{Cr}$-labeled SB target cells. Percentage inhibition of NK and ADCC activities by AMB was calculated as follows:

$\%$ inhibition $=\frac{\begin{array}{c}\% \text { cytotoxicity of control lymphocytes } \\ -\% \text { cytotoxicity of AMB treated lymphocytes }\end{array}}{\% \text { cytotoxicity of control lymphocytes }} \times 100$.

Assay to measure suppressor cell activity. For mixing experiments to measure suppressor cell activity, precultured PBL were added separately to a suspension of effector and prelabeled target cells. The observed cytotoxicity demonstrated by the cell mixture was compared to the sum of cytotoxicities shown by precultured PBL and effector cells when tested alone. In mixing experiments, an effector to target (E:T) cell ratio of 50:1 was maintained while suppressor to effector (S:E) cell ratios ranged between $1: 1,2: 1$, and 3:1. All plates were treated as described for the cytotoxicity assay. Percentage of suppression mediated by PBL precultured with or without AMB was calculated as detailed elsewhere $(16,26)$ or as follows:

$$
\% \text { suppression }=\frac{\text { predicted cytotoxicity }- \text { observed cytotoxicity }}{\text { predicted cytotoxicity }} \times 100
$$

where predicted cytotoxicity is calculated as the sum of the cytotoxicities of effector cells plus precultured PBL and observed cytotoxicity is the cytotoxicity demonstrated by the mixture of effector and precultured PBL. Results are expressed as mean values \pm SEM. The statistical significances of differences in mean values were determined using a paired $t$ test formula by Dr. Ken Guire of the Biostatistics Computing Laboratory of The University of Michigan.

\section{RESULTS}

\section{Preculture of PBL with $A M B$ Decreases $N K$ and $A D C C$ Activities}

In view of the findings that $A M B$ exerts significant immunosuppressive and immunostimulatory effects on various immunologic functions in man and mice, the influence of AMB on NK and ADCC activities of human PBL was examined. AMB added at different concentrations, ranging from 0.1 to $10 \mu \mathrm{g} / \mathrm{ml}$, to the reaction mixture of fresh effector and prelabeled target cells and incubated for 4 $\mathrm{hr}$, showed no significant effect on NK activity (data not presented). Table 1 shows that cell viability as determined by trypan blue dye exclusion was unaffected by preincubating PBL with AMB for $48 \mathrm{hr}$ at concentrations $\leq 5 \mu \mathrm{g} / \mathrm{ml}$ and was 
TABLE 1

Effect of AMB on Viability of PBLa

\begin{tabular}{|c|c|c|c|c|c|c|c|}
\hline & \multicolumn{7}{|c|}{ Viability } \\
\hline & \multirow[b]{2}{*}{$\begin{array}{c}\text { Control } \\
(\%)\end{array}$} & \multicolumn{6}{|c|}{ AMB concentrations $(\mu \mathrm{g} / \mathrm{ml})$} \\
\hline & & $\begin{array}{c}0.1 \\
(\%)\end{array}$ & $\begin{array}{l}0.5 \\
(\%)\end{array}$ & $\begin{array}{c}1 \\
(\%)\end{array}$ & $\begin{array}{c}2.5 \\
(\%)\end{array}$ & $\begin{array}{c}5 \\
(\%)\end{array}$ & $\begin{array}{c}10 \\
(\%)\end{array}$ \\
\hline Mean & 93.6 & 91.4 & 95.2 & 92.6 & 89.2 & 88.9 & 75.23 \\
\hline$\pm \mathrm{SEM}$ & 3.1 & 3.1 & 2.5 & 4.9 & 2.9 & 3.1 & 16.7 \\
\hline
\end{tabular}

a Lymphocytes precultured with and without AMB for $48 \mathrm{hr}$, washed, and tested for viability by trypan blue dye exclusion. Values represent mean percentage viability \pm SEM of three separate experiments.

comparable with control cultures. Kinetics of the effect of AMB on NK and ADCC activities of PBL showed that PBL precultured with $2.5 \mu \mathrm{g} \mathrm{AMB}$ for 0 to $24 \mathrm{hr}$ did not exhibit any significant inhibitory effect on either NK or ADCC activity. However, PBL preincubated with AMB for 48 to $72 \mathrm{hr}$ showed significantly decreased NK and ADCC activities (Table 2). Consistent with these findings, PBL precultured with AMB for $48 \mathrm{hr}$ were used in all subsequent experiments. The dose-response effect of AMB on NK and ADCC activities (Table 3) demonstrated that PBL precultured with $2.5 \mu \mathrm{g} \mathrm{AMB} / \mathrm{ml}$ for $48 \mathrm{hr}$ showed significant inhibition of NK and ADCC activities without affecting viability of lymphocytes; therefore, this concentration was used for all subsequent experiments. Table 4 demonstrates decreased NK and ADCC activities of PBL preincubated with AMB at several

TABLE 2

Kinetics of Inhibition of NK and ADCC Activities of PBL Preincubated with AMB ${ }^{a}$

\begin{tabular}{|c|c|c|c|c|c|}
\hline \multirow{2}{*}{$\begin{array}{c}\text { Time of } \\
\text { incubation } \\
(\mathrm{hr})\end{array}$} & \multirow[b]{2}{*}{$\begin{array}{l}\text { AMB } \\
\text { added }\end{array}$} & \multicolumn{2}{|c|}{$\mathbf{N K}^{b}$} & \multicolumn{2}{|c|}{$\mathrm{ADCC}^{c}$} \\
\hline & & $\begin{array}{c}\text { Cytotoxicity } \\
(\%)\end{array}$ & $\begin{array}{c}\text { Inhibition } \\
\qquad \%)\end{array}$ & $\begin{array}{c}\text { Cytotoxicity } \\
(\%)\end{array}$ & $\begin{array}{c}\text { Inhibition } \\
(\%)\end{array}$ \\
\hline \multirow[t]{2}{*}{0} & - & 61.0 & - & 38.6 & - \\
\hline & + & 58.6 & 3.9 & 36.1 & 6.4 \\
\hline \multirow[t]{2}{*}{24} & - & 49.4 & - & 33.7 & - \\
\hline & + & 44.8 & 9.3 & 31.4 & 6.8 \\
\hline \multirow[t]{2}{*}{48} & - & 36.8 & - & 35.2 & - \\
\hline & + & 16.8 & 54.3 & 14.2 & 59.6 \\
\hline \multirow[t]{2}{*}{72} & - & 36.6 & - & 36.6 & - \\
\hline & + & 15.9 & 56.5 & 12.31 & 66.4 \\
\hline
\end{tabular}

${ }^{a}$ PBL preincubated with and without $(2.5 \mu \mathrm{g} / \mathrm{ml})$ AMB for 0 to $72 \mathrm{hr}$ were washed and tested for NK and ADCC activities at a 50:1 E:T ratio. Cytotoxicity and inhibition were calculated as under Materials and Methods. Results are from a representative experiment and four separate experiments gave similar results.

${ }^{b}$ NK activity was measured against the human erythroleukemia cell line K-562.

' ADCC activity measured against the human B-lymphoblast cell line, SB, sensitized with anti-SB sera. 
TABLE 3

Dose-Response Effect of AMB on NK and ADCC Activities of PBL ${ }^{a}$

\begin{tabular}{|c|c|c|c|c|}
\hline \multirow{2}{*}{$\begin{array}{c}\text { AMB } \\
\text { concentration } \\
(\mu \mathrm{g} / \mathrm{ml})\end{array}$} & \multicolumn{2}{|c|}{$N^{b}$} & \multicolumn{2}{|c|}{$\mathrm{ADCC}^{c}$} \\
\hline & $\begin{array}{c}\text { Cytotoxicity } \\
(\%)\end{array}$ & $\begin{array}{c}\text { Inhibition } \\
(\%)\end{array}$ & $\begin{array}{c}\text { Cytotoxicity } \\
(\%)\end{array}$ & $\begin{array}{c}\text { Inhibition } \\
(\%)\end{array}$ \\
\hline 0 & 36.7 & - & 36.6 & - \\
\hline 0.1 & 32.5 & 11.4 & 30.1 & 17.7 \\
\hline 1.0 & 28.5 & 22.3 & 28.4 & 22.4 \\
\hline 2.5 & 21.6 & 41.1 & 19.8 & 45.9 \\
\hline 5.0 & 15.9 & 56.7 & 12.3 & 66.4 \\
\hline 10.0 & 10.0 & 72.7 & 11.6 & 68.3 \\
\hline
\end{tabular}

${ }^{a}$ PBL preincubated with AMB $(0.1$ to $10 \mu \mathrm{g} / \mathrm{ml})$ for $48 \mathrm{hr}$ were washed and tested for NK and ADCC activities at a 50:1 E:T ratio. Cytotoxicity and inhibition of cytotoxicity were calculated as under Materials and Methods. Results are from a representative experiment and four separate experiments gave similar results.

${ }^{b}$ NK activity measured against the human erythroleukemia cell line K-562.

'ADCC activity measured against the human B lymphoblast cell line, SB, sensitized with anti-SB sera.

E:T cell ratios compared to PBL preincubated in media alone. It is evident that the inhibitory effect of AMB on ADCC and NK activities occurs even at high E:T ratios.

PBL precultured with and without AMB were tested against various prelabeled targets in NK and ADCC assays. The data presented in Fig. 1 reveal that lymphocytes precultured in media alone for $48 \mathrm{hr}$ display a significantly lower NK activity against K-562 $(23 \%, P<0.03)$ and CEM $(9 \%, P<0.01)$ targets compared to the higher NK activity shown by fresh PBL against K-562 (50\%) and CEM

TABLE 4

NK and ADCC Activities of PBL Precultured with AMB at Varying Effector to Target Cell Ratios ${ }^{a}$

\begin{tabular}{lcccc}
\hline & & \multicolumn{3}{c}{ Cytotoxicity } \\
\cline { 3 - 4 } Target & & \multicolumn{3}{c}{ E:T ratios } \\
\cline { 3 - 4 } cells & AMB & $10: 1$ & $50: 1$ & $100: 1$ \\
NK $^{b}$ & added & $(\%)$ & $(\%)$ & $(\%)$ \\
(K-562) & - & 22.8 & 40.2 & 52.1 \\
ADCC & + & 7.1 & 12.7 & 12.1 \\
(SB) & - & 35.3 & 47.3 & 46.6 \\
\hline
\end{tabular}

\footnotetext{
- PBL precultured with and without AMB $(2.5 \mu \mathrm{g} / \mathrm{ml})$ for $48 \mathrm{hr}$ were washed and tested for NK and ADCC activities. Cytotoxicity was calculated as under Materials and Methods. Results are from a representative experiment and four separate experiments gave similar results.

${ }^{6} \mathrm{NK}$ activity measured against the human erythroleukemia cell line $\mathrm{K}-562$.

${ }^{c}$ ADCC activity measured against the human B lymphoblast cell line, SB, sensitized with anti-SB sera.
} 


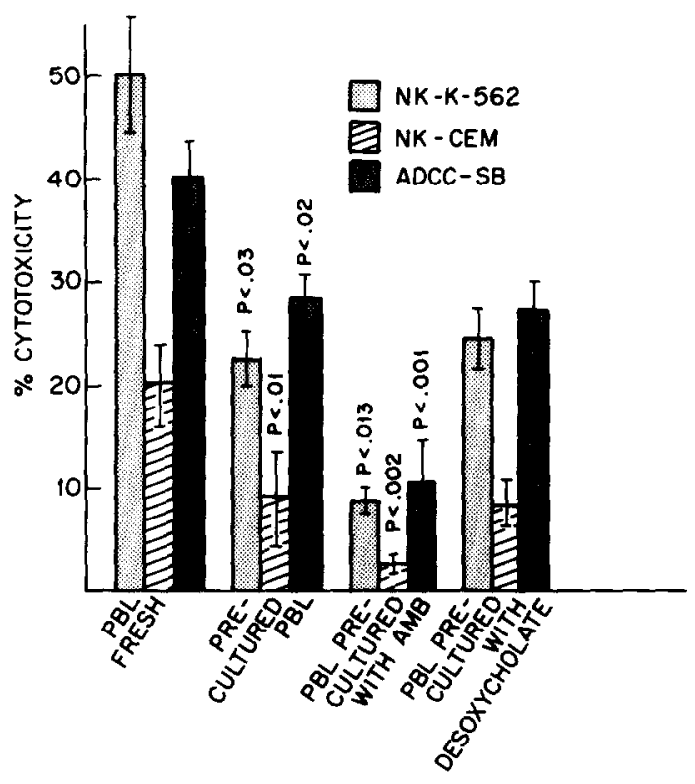

FIG. 1. NK and ADCC activities of PBL precultured with AMB. Fresh total PBL or total PBL precultured in media alone with either AMB $(2.5 \mu \mathrm{g} / \mathrm{ml})$ or SD $(2.5 \mu \mathrm{g} / \mathrm{ml})$ for $48 \mathrm{hr}$ were washed and their NK or ADCC activities were measured. Results are expressed as mean percentage cytotoxicity \pm SEM of four separate experiments with triplicate determinations for each experiment at a 50:1 E:T ratio.

(20\%) targets. PBL precultured in media alone also manifested lower ADCC activity $(28 \%, P<0.02)$ compared to a higher (40\%) ADCC activity displayed by fresh autologous PBL. PBL precultured with AMB display significantly lower levels of NK activity against K-562 (9\%, $P<0.013)$ and CEM $(2 \%, P<0.002)$ targets, respectively, compared to higher NK activities (23 and $9 \%$, respectively, for K-562 and CEM targets) manifested by PBL precultured in media alone. PBL precultured

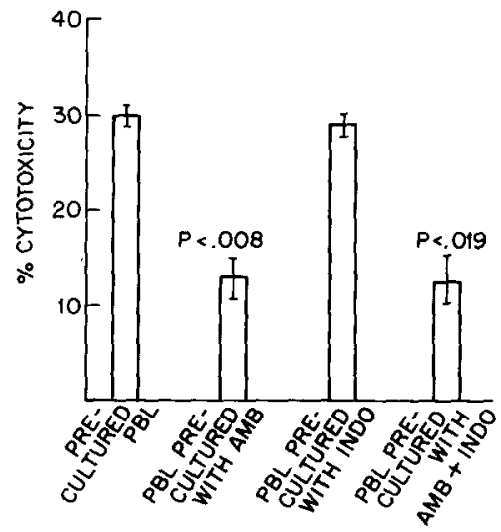

FIG. 2. Effect of indomethacin on AMB-induced suppression of ADCC. Total PBL precultured alone or with (1) AMB $(2.5 \mu \mathrm{g} / \mathrm{ml})$, (2) INDO (1 $\mu \mathrm{g} / \mathrm{ml})$, or (3) AMB + INDO for $48 \mathrm{hr}$ were washed and tested for their ADCC activity. Results are expressed as mean percentage cytotoxicity \pm SEM of four separate experiments with triplicate determinations for each experiment at an E:T ratio of 50:1. 
TABLE 5

ADCC Activity of Lymphocyte Subpopulations Precultured with AMB

\begin{tabular}{lc} 
Precultured effector cells & $\begin{array}{c}\text { ADCC activity } \\
\text { (\%) }\end{array}$ \\
\hline I. Total MNC & 40.4 \\
Total MNC + AMB & 20.8 \\
II. G-10 separated PBL ${ }^{d}$ & 39.7 \\
G-10 separated PBL + AMB & 17.5 \\
III. T cells & 46.3 \\
T cells + AMB & 24.7 \\
IV. Non-T cells & 70.6 \\
Non-T cells + AMB & 58.4 \\
\hline
\end{tabular}

a Lymphocytes precultured with and without AMB $(2.5 \mu \mathrm{g} / \mathrm{ml})$ for $48 \mathrm{hr}$ were washed twice and tested for their ADCC activity.

"Human B-cell leukemia line "SB" was used as targets. Percentage cytotoxicity was calculated as described under Materials and Methods. Values represent mean percentage ADCC activity of a representative experiment. Three separate experiments gave identical results. Viability of subpopulations below was always $>95 \%$ by tyrpan blue dye exclusion.

c Total peripheral blood mononuclear cells separated as described under Materials and Methods. Estimation of latex ingesting phagocytic cells and nonspecific esterase positive cells varied from 12 to $15 \%$ and 11 to $14 \%$, respectively.

${ }^{d}$ Monocytes/macrophages were depleted by passage through a G-10 column as described under Materials and Methods, and always contained $<3 \%$ latex ingesting and $<2 \%$ nonspecific esterase positive cells.

- $T$ cells were separated by rosetting with neuraminidase-treated SRBC as described under Materials and Methods, and contained $>92 \%$ E-rosette positive cells; $<0.5 \%$ fluorescent, polyvalent surface Igbearing cells; and $<1 \%$ nonspecific esterase positive and latex ingesting phagocytic cells.

${ }^{f}$ Nonrosetted lymphocytes separated from rosetted $\mathrm{T}$ cells on an FH gradient. Non- $\mathrm{T}$ cells contained $<2 \%$ E-rosette ${ }^{+}$cells and $<0.5 \%$ nonspecific esterase positive and latex ingesting cells.

with AMB also showed significantly lower ADCC activity $(10 \%, P<0.001)$ compared to a higher level of ADCC (28\%) displayed by PBL precultured in media alone. PBL precultured with SD at concentration equivalent to that used with AMB did not manifest any decrease in NK and ADCC activity against either target, and was comparable with NK and ADCC activities displayed by PBL precultured in media alone. PBL precultured with SD at concentration equivalent to that used with AMB did not manifest any decrease in NK and ADCC activity against either target, and was comparable with NK and ADCC activities displayed by PBL precultured in media alone. The results thus demonstrate that precultured PBL show decreased levels of NK and ADCC activity compared to fresh PBL and these activities are further decreased when PBL are precultured with AMB.

\section{AMB-Induced Suppression Is Not Reversed by Indomethacin}

Studies were undertaken to examine whether AMB-induced suppression is mediated via prostaglandin ( $\mathrm{PG}$ )-producing cells; $\mathrm{PBL}$ were precultured either with $1 \mu \mathrm{g} \mathrm{INDO} / \mathrm{ml}$, a potent inhibitor of PG synthesis, or with INDO + AMB (2.5 $\mu \mathrm{g} / \mathrm{ml}$ ) for $48 \mathrm{hr}$ and tested for ADCC activity (Fig. 2). INDO at 0.1 and 2.5 $\mu \mathrm{g} / \mathrm{ml}$ gave identical results (data not shown). PBL precultured with AMB dis- 


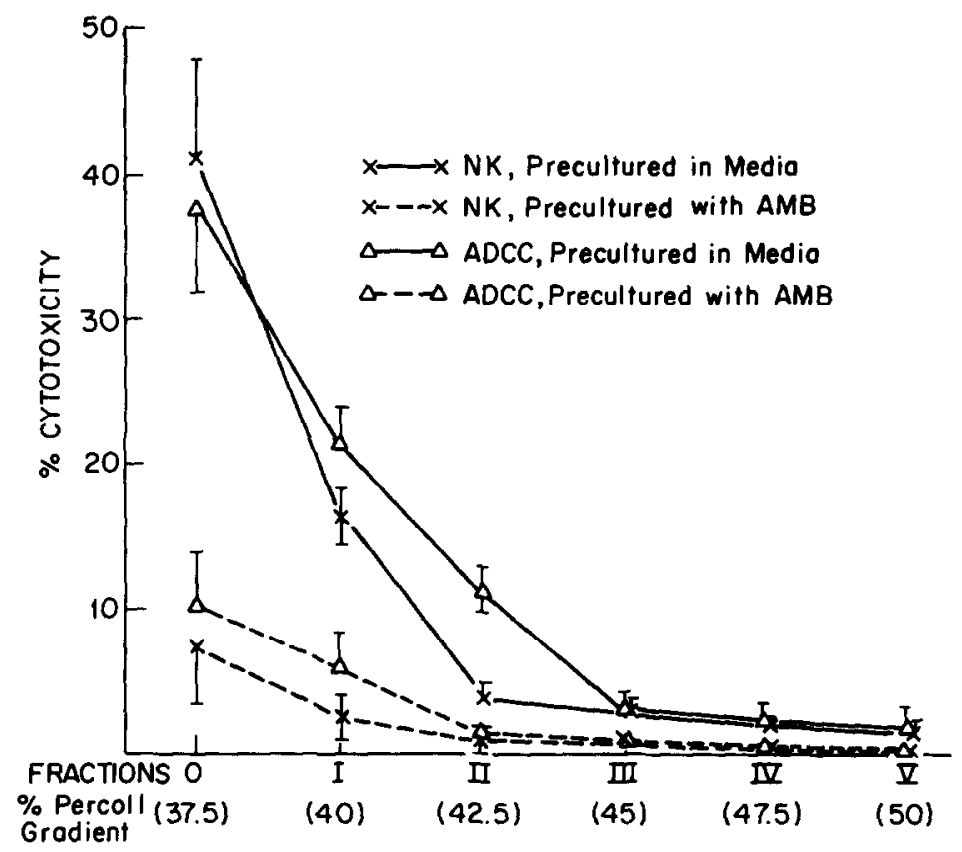

FIG. 3. Effect of AMB on Percoll gradient fractionated PBL. PBL depleted of monocytes/macrophages were separated on a discontinuous Percoll gradient as under Materials and Methods. Values represent mean percentage cytotoxicity \pm SEM of four separate experiments with triplicate determinations for each experiment at a 10:1 E:T ratio. All Percoll separated cell fractions contained $<0.5 \%$ esterase positive cells.

played a decreased level of ADCC activity ( $13 \%, P<0.008)$ compared to higher cytotoxicity $(30 \%)$ demonstrated by PBL precultured in media alone. PBL precultured with INDO alone did not show any inhibition of ADCC activity (29\%) compared to a significantly lower level of cytotoxicity $(13 \%, P<0.019)$ manifested by PBL preincubated with INDO + AMB. These results suggest that AMB-induced suppression of ADCC activity is not mediated by PG-producing cells.

\section{Effect of AMB on ADCC Activity of Lymphocyte Subpopulations}

To investigate the effect of AMB on different lymphocyte subpopulations, total mononuclear cells (MNC), G-10 passed PBL (monocyte/macrophage-depleted), $T$ cells and non-T lymphocytes were cultured with and without AMB for $48 \mathrm{hr}$ and tested for ADCC activity against antibody-coated SB target cells. Results of a representative experiment are shown in Table 5. Total MNC, G-10 passed PBL, and $T$ cells precultured with AMB displayed significantly decreased ADCC activities, i.e., 21,17 , and $25 \%$, respectively, as contrasted with higher ADCC activities $(40,40$, and $46 \%$, respectively) manifested by lymphocytes precultured in media alone. Non-T cells precultured with AMB did not show significant $(P<0.55)$ decrease in ADCC activity (58\%) compared to non-T cells (71\%) precultured in media alone. The results suggest that AMB may have an immunomodulating effect on regulatory $\mathrm{T}$ cells. 


\section{TABLE 6}

Effect of Fresh Lymphocytes, Cultured Lymphocytes, and Heat-Killed Lymphocytes on ADCC and NK Activities of Fresh Effector Cells ${ }^{a}$

\begin{tabular}{lcc}
\hline & \multicolumn{2}{c}{ Percentage suppression $^{b}$} \\
\cline { 3 - 3 } Source of suppressor cells & \multicolumn{1}{c}{$\mathrm{NK}^{c}$} & ADCC $^{d}$ \\
\hline Precultured PBL & & \\
PBL precultured in media alone & $27.4 \pm 3.7$ & $41.2 \pm 8.6$ \\
& $(P<0.55)$ & $(P<0.006)$ \\
PBL precultured with AMB & $32.8 \pm 5.2$ & $62.4 \pm 6.5$ \\
Fresh lymphocytes & & \\
47.5\% Percoll fraction IV & $3.9 \pm 0.4$ & $-8.4 \pm 0.4$ \\
50\% Percoll fraction V & $-3.2 \pm 0.5$ & $-8.0 \pm 0.5$ \\
Heat killed PBL & & \\
PBL precultured in media alones & $7.9 \pm 1.1$ & $11.2 \pm 2.1$ \\
PBL precultured with AMB & $10.2 \pm 2.4$ & $7.5 \pm 0.3$ \\
Fresh PBL & $3.3 \pm 1.8$ & $3.6 \pm 0.4$ \\
\hline
\end{tabular}

\footnotetext{
${ }^{a}$ Fresh autologous effector PBL were depleted of phagocytic cells as described under Materials and Methods. A constant E:T cell ratio of 50:1 was maintained. E:S cell ratios of 1:1, 1:2, and 1:3 were used and a dose-dependent effect was observed, but only the results of $1: 1 \mathrm{E}: \mathrm{S}$ cell ratio are presented.

${ }^{b}$ Percentage suppression of cytotoxicity calculated as under Materials and Methods. Results are expressed as the mean of three separate experiments \pm SEM. Negative $(-)$ values indicate enhancement.

${ }^{c}$ Percentage suppression of cytotoxicity against prelabeled K-562 cells.

${ }^{a}$ Percentage suppression of cytotoxicity against antibody-coated SB targets.

e Fresh lymphocytes separated on discontinuous Percoll density gradient at 47.5 and $50 \%$ Percoll.

${ }^{f}$ Lymphocytes heat killed at $56^{\circ} \mathrm{C}$ for $10 \mathrm{~min}$.

${ }^{8} \mathrm{PBL}$ precultured in media alone for $48 \mathrm{hr}$.

${ }^{\text {h }}$ PBL precultured with AMB for $48 \mathrm{hr}$.

'Fresh PBL depleted of phagocytic cells as under Materials and Methods.
}

\section{Effects of AMB on NK- and ADCC-Enriched Fractions}

Enrichment of human NK cells using discontinuous Percoll density gradient centrifugation was reported by Timonen and Saksela (21). We investigated the sedimentation characteristics of human ADCC cells in a Percoll density gradient and observed that ADCC activity against target SB cells peaked in the low density (37.5\% Percoll) fraction "0" (Fig. 3). At an E:T ratio of 10:1, lymphocytes from fraction " 0 " displayed $38 \%$ ADCC activity compared to $22,12,6,2$, and $1 \%$ activity shown by fractions 1 through 5 , respectively.

To examine the effect of AMB on NK- and ADCC-enriched subpopulations, Percoll separated lymphocyte fractions were precultured with and without AMB for $48 \mathrm{hr}$, washed, and tested for their NK and ADCC activities against prelabeled target cells. The data presented in Fig. 3 reveal that NK- and ADCC-enriched cells from fraction " 0 " cultured with AMB showed significantly diminished levels of NK (8\%) and ADCC (11\%) activities compared to the NK (42\%) and ADCC (38\%) activities displayed by the same lymphocyte fraction precultured in media alone. Lymphocytes from fraction "I," precultured with AMB, also manifested significantly lower levels of NK (3\%) and ADCC (7\%) activities as contrasted with 
higher levels of NK (16\%) and ADCC (21\%) activities manifested by the same lymphocyte fraction cultured in media alone. Lymphocytes from fractions II to $\mathrm{V}$, cultured with and without AMB, did not manifest significant differences in NK or ADCC activities. The results indicate that NK and ADCC activities of enriched effector cells, separated by discontinuous Percoll density gradient, are significantly inhibited by preculture with AMB as compared to similar cells precultured in media alone.

\section{Effect of Precultured PBL, and Heat-Killed PBL on NK and ADCC Activity of Autologous Effector Cells}

Studies were undertaken to examine whether PBL precultured with AMB were able to suppress NK and ADCC activity of fresh effector cells. In mixing experiments to measure suppression, precultured PBL were added separately to a mixture of fresh effector and prelabeled target cells, and the percentage of suppression was calculated as detailed elsewhere $(16,26)$. Results are presented in Table 6. PBL precultured with AMB for $\mathbf{4 8} \mathrm{hr}$ demonstrated 33\% suppression of the NK activity of autologous fresh effector cells compared to $27 \%$ suppression by PBL precultured in media alone $(P<0.55)$. PBL precultured with AMB significantly suppressed the ADCC activity of autologous effector cells, the percentage of suppression being $62 \%$ compared to $41 \%$ suppression manifested by PBL precultured in media alone $(P<0.006)$.

To rule out the possibility that crowding, steric hindrance, or cell death could cause the suppression of ADCC activities, we examined the effect of (i) cytolytically inactive viable lymphocytes (filler) obtained from discontinuous Percoll gradient (fraction IV and V), (ii) PBL preincubated with and without AMB and then heat killed, and (iii) heat-killed fresh effector cells, on NK or ADCC activities of autologous fresh effector cells (Table 6). The results demonstrate that addition of viable cytolytically inactive cells (fraction IV and V) or-heat killed fresh PBL and PBL precultured with and without AMB and then heat killed, as inhibitor cells to the reaction mixture at effector:inhibitor ratio of 1:1 did not produce any significant suppression of NK or ADCC activities of fresh PBL against respective target cells. The results thus suggest that suppression of ADCC activity by AMBinduced suppressor cells observed in the present studies was not caused by crowding, steric hindrance, or cell death, but by functionally active, viable, suppressor cells.

\section{DISCUSSION}

AMB is currently used as a primary therapeutic agent for the treatment of many systemic mycoses. Patients with localized or disseminated fungal infections often show suppressed immune responses (27-30). Evidence now suggests that NK or ADCC effector cells are involved in host defense against tumors and in the regulation of lymphoid cell reactions (10-16, 22). We report here a previously unrecognized immunosuppressive effect of $A M B$ on NK and ADCC activity of normal lymphocytes, i.e., PBL precultured with AMB decrease the cytotoxic potential of NK and ADCC activities. AMB also specifically affects NK- and ADCC-enriched fractions and isolated $\mathrm{T}$ cells, and the suppression is not mediated by monocytes/ macrophages or by PGs. In mixing experiments, PBL precultured with AMB also 
expressed suppressor functions on the ADCC activity of fresh autologous effector cells.

On preculturing PBL in media alone for $48 \mathrm{hr}$, both NK and ADCC activities decreased compared to those of fresh PBL, presumably as a consequence of the induction of endogenous suppressor cells on culture (Fig. 1). This is consistent with our earlier report (16) that both NK and ADCC activities decreased with the time of preculture, and precultured PBL were able to exert suppressor effects on NK or ADCC activity of allogeneic PBL. Activation of suppressor cells by culturing lymphoid cells has also been reported and tested in murine and human models against both humoral and cellular immune responses (26, 31-36). Schwartz and his colleagues (37) observed that mononuclear cells precultured for $48 \mathrm{hr}$ suppressed Ig synthesis by PWM-stimulated PBL. The present study shows that suppressor cell activities could be further enhanced by preculturing PBL with AMB presumably as a result of activating endogenous suppressor cells by AMB during culture.

Studies on immunomodulating effects of AMB on normal lymphocyte functions in the human have been reported. Roselle and Kauffman (7) demonstrated that AMB significantly suppressed both spontaneous lymphocyte transformation and the response of lymphocytes to stimulation with streptokinase-streptodornase. Recently Stewart and colleagues (8) showed that AMB reduced PHA-induced $\left[{ }^{3} \mathrm{H}\right]$ thymidine incorporation into normal PBL as a consequence of suppressor cell induction. Tarnvik and Ansehn (6) observed reduced lymphocyte transformation responses to PHA, Con A, PPD, PWM, and allogeneic cells in the presence of AMB.

Timonen and Saksela (21) recently described sedimentation characteristics of human NK cells against the K-562 cell line by using a discontinuous Percoll density gradient. In the present study, we report a sedimentation profile of human ADCC effector cells against the human leukemia cell line "SB." This ADCC activity peaked in a single low-density Percoll gradient fraction (37.5\%); therefore, Percoll density gradient centrifugation also provides a useful tool for analysis of human ADCC cells. Our study further reveals that AMB exerts a suppressive effect on NK or ADCC effector cells (Fig. 3), and Percoll separated NK- and ADCCenriched fractions cultured with AMB showed a remarkably low level of NK or ADCC activity compared to that of untreated cells.

In our studies, we ruled out the possibility that AMB-induced suppression is mediated via PG-producing cells like monocytes/macrophages (Fig. 2), since INDO failed to inhibit the activity of AMB-induced suppressor cells. This is consistent with the report of Stewart and colleagues (8) who showed that INDO did not reverse the AMB suppression of PBL responses to PHA, suggesting the suppressor activity described was not due to PG secretion. Droller et al. (38) and Brunda et al. (39) demonstrated that pretreatment of effector cells with PG had minimal inhibitory effect on either ADCC or NK activity. In the present study, purified T cells, Percoll separated NK- and ADCC-enriched fractions, and G-10 passed PBL precultured with AMB all manifested remarkably reduced NK and ADCC activities, suggesting that monocytes/macrophages, known to produce significant amounts of PGs, had minimal suppressive effects on these activities.

In coculture experiments, PBL precultured with AMB significantly suppressed ADCC but not NK activity of fresh autologous effector cells. The reasons for this dichotomy are not clear. It is possible that AMB-induced regulatory cells may 
differentially recognize effector cells mediating NK or ADCC activities. This is consistent with other reports which demonstrate that NK or ADCC effector cells are distinct subpopulations, and their recognition and binding mechanisms also appear to be different $(16,40,41)$. It is also likely that NK-specific regulatory cells may incompletely suppress the NK activity of fresh effector cells during a 4-hr reaction period as some suppression of NK activity is consistently observed although it is not statistically significant. Preincubation of putative suppressor and effector cells may be necessary before mixing with highly sensitive target cells to mediate significant suppression of NK cytotoxicity. Alternatively, the presence of a soluble suppressor factor may be necessary to mediate NK suppression requiring a longer time for its further synthesis. ${ }^{4}$ Experiments are currently investigating these possibilities.

To ensure that suppression induced by PBL preincubated with AMB on fresh $\mathrm{ADCC}$ effector cells was the result of functionally activated cells, the following control experiments were set up. (i) Addition of viable lymphocytes obtained from Percoll fractionation (fractions IV and V), which were neither cytolytically active nor susceptible themselves to NK and ADCC activity, to the reaction mixture of effector and target cells did not manifest any significant suppressor effect on the ADCC activity of autologous lymphocytes (Table 6). (ii) Addition of heat-killed fresh PBL or PBL precultured with and without AMB, and then heat killed to the reaction mixture, did not produce any significant effect on the ADCC activities of fresh autologous effector cells. Thus we ruled out the possibility that suppression was nonspecifically caused by cell crowding, steric hindrance, or cell death, but was a consequence of functionally activated viable suppressor lymphocytes.

Experiments were also designed to examine whether AMB-activated PBL could lead to generation of cytotoxic cells causing lysis of effector cells themselves, or cells causing cold target competitive binding, or inhibition of the effector cells due to potential target antigenic determinants. We found no evidence of cytotoxic activity against effector cells or the presence of lymphocytes causing cold target competitive inhibition or binding (data not shown). Furthermore, the suppression observed was not due to nonspecific toxicity due to SD which is supplied with AMB as a solubilizer, since PBL precultured with $\mathrm{SD}$ at concentrations equivalent to those obtained in the AMB solutions did not manifest any greater suppressor effect on NK or ADCC activities than control cells precultured with media alone (Fig. 1). Experiments were also designed to study whether AMB affects the sensitivity of target cells to lysis by fresh effector cells; ${ }^{51} \mathrm{Cr}$-labeled target cells were preincubated with AMB $(2.5 \mu \mathrm{g} / \mathrm{ml})$ for $30 \mathrm{~min}$ at $37^{\circ} \mathrm{C}$, washed, and used as targets in NK and ADCC assays. The results demonstrated that preincubation of either K-562 or SB targets with AMB did not affect the sensitivity of targets to lysis by effector cells (data not shown). Thus it appears that AMB-induced suppression of ADCC activity of fresh effector cells is not due to cell death, cell crowding, or steric hindrance. Rather, it appears to activate endogenous suppressor cells which in turn inhibit the functional assays described. These results suggest that like other immunomodulating agents, AMB also regulates various lymphoid functions like NK and ADCC activities, which may be of clinical importance.

\footnotetext{
${ }^{4}$ Nair, M. P. N., and Schwartz, S. A. Suppression of human natural and antibody dependent cytotoxicity by soluble factors from unstimulated normal lymphocytes (submitted for publication).
} 


\section{ACKNOWLEDGMENTS}

The authors wish to express their sincere appreciation to Dr. Thomas C. Shope of Wayne State University for his helpful suggestions, Mary Burton for her technical assistance, and to Ms. Joan McClain for her expert secretarial assistance.

\section{REFERENCES}

1. Blanke, T. J., Little, J. R., Shirley, S. F., and Lynch, R. G., Cell. Immunol. 33, 180, 1977.

2. Hammarstrom, L., and Smith, C. I. E., Acta Pathol. Microbiol. Scand. 85, 277, 1977.

3. Ishikawa, H., Narimatsu, H., and Saito, K., Cell. Immunol. 17, 300, 1975.

4. Shirley, S. F., and Little, J. R., J. Immunol. 123, 2878, 1979.

5. Shirley, S. F., and Little, J. R., J. Immunol. 123, 2883, 1979.

6. Tarnvik, A., and Ansehn, S., Antimicrob. Agents Chemother. 6, 529, 1974.

7. Roselle, G. A., and Kauffman, C. A., Antimicrob. Agents Chemother, 14, 398, 1978.

8. Stewart, S. J., Spagnuolo, P. J., and Eliner, J. J., J. Immunol. 127, 135, 1981.

9. Marmer, D. J., France, G. L., and Steele, R. W., Clin. Res. 28, 864A, 1980 (abstract).

10. Calder, E. A., Penhale, W. J., McLeman, D., Barnes, E. W., and Irvine, W. J., Clin. Exp. Immunol. 14, 153, 1973.

11. Hersey, P., Cullen, P., and MacLennan, I. C. M., Transplant. (Baltimore) 16, 9, 1973.

12. O'Toole, C., Stejskal, V., Perlmann, P., and Karlsson, M., J. Exp. Med. 139, 457, 1974.

13. Herberman, R. B., and Holden, H. T., In "Advances in Cancer Research" (G. Klein and S. Weinhouse, Eds.), Vol. 27, p. 305. Academic Press, New York, 1978.

14. Cudkowitz, G., and Hochman, P. S., Immunol. Rev. 44, 13, 1979.

15. Perlmann, P., Troye, M., Pape, G. R., Herfast, B., and Anderson, T., In "Perspective in Immunology" (G. Riethmuller, P. Wernet, and G. Cudkowicz, Eds.), p. 29. Academic Press, New York, 1979.

16. Nair, M. P. N., and Schwartz, S. A., J. Immunol. 126, 2221, 1981.

17. Boyum, A., J. Clin. Lab. Invest. 21, 77, 1968.

18. Ly, A. I., and Mischell, R. E., J. Immunol. Methods 5, 239, 1974.

19. Berlinger, N. T., Lopez, C., Lipkin, M., Vogel, J. E., and Good, R. A., J. Clin. Invest. 59, 761, 1977.

20. Gupta, S., Schwartz, S. A., and Good, R. A., Cell. Immunol. 44, 242, 1979.

21. Timonen, T., and Saksela, E., J. Immunol. Methods 36, 285, 1980.

22. Nair, M. P. N., Schwartz, S. A., Fernandes, G., Pahwa, R., Ikehara, S., and Good, R. A., Cell. Immunol. 58, 9, 1981.

23. Nair, P. N. M., Fernandes, G., Onoe, K., Day, N. K., and Good, R. A., Int. J. Cancer 25, 667, 1980.

24. Perlmann, P., and Perlmann, H., Cell. Immunol. 1, 300, 1970.

25. Handwerger, B. S., and Koren, H. S., Clin. Immunol. Immunopathol. 5, 272, 1976.

26. Pollack, S. B., and Herrick, M. V., J. Immunol. 119, 2172, 1977.

27. Stobo, J. D., Paul, S., Vanscoy, S. E., and Hermans, P. E., J. Clin. Invest. 57, 319, 1976.

28. Diamond, R. D., and Bennett, J. E., J. Infect. Dis. 127, 694, 1973.

29. Mendes, N., Musati, C. C., Leao, R. C., Mendes, E., and Naspitz, C. K., J. Allergy 48, 40, 1971.

30. Graybill, J. R., and Alford, R. H., Cell. Immunol. 14, 12, 1974.

31. Haynes, B. F., and Fauci, A. S., Cell. Immunol. 36, 294, 1978.

32. Burns, F. D., Marrack, P. C., Kappler, J. W., and Janeway, C. A., J. Immunol. 114, 1345, 1975.

33. Hodes, R. J., and Hathcock, H. S., J. Immunol. 116, 167, 1976.

34. Rollwagen, F. M., and Stutman, O., J. Exp. Med. 150, 1359, 1979.

35. Saxon, A., Stevens, R. H., and Ashman, R. F., J. Immunol. 118, 1872, 1977.

36. Lipsky, P. E., Ginsburg, W. W., Finkelman, F. D., and Ziff, M., J. Immunol. 120, 902, 1978.

37. Schwartz, S. A., Shou, L., Good, R. A., and Choi, Y. S., Proc. Nat. Acad. Sci. USA 74, 2099, 1977.

38. Droller, M. M., Perlmann, P., and Schneider, M. U., Cell. Immunol. 39, 154, 1978.

39. Brunda, M. J., Herberman, R. B., and Holden, H. T., J. Immunol. 124, 2682, 1980.

40. Kay, H. D., Bonnard, G. D., and Herberman, R. B., J. Immunol. 122, 675, 1979.

41. Koren, H. S., and Williams, M. S., J. Immunol. 121, 1956, 1978. 